\title{
GEOTECHNICAL CHARACTERIZATION AND RISK ANALYSIS OF URBAN SLOPE INSTABILITY IN THE CITY OF ARACAJU - BRAZIL
}

\author{
B. G. SANTOS NETA ${ }^{1}$, O. DE FREITAS NETO ${ }^{2}$, E. H. CAVALCANTE ${ }^{3}$
}

Universidade de Brasília ${ }^{1}$, Universidade Federal do Rio Grande do Norte ${ }^{2}$, Universidade Federal de Sergipe ORCID ID: https://orcid.org/0000-0002-1877-9353 ${ }^{1}$ belanizagsn@gmail.com ${ }^{1}$

DOI: $10.15628 /$ holos.2020.10067

\begin{abstract}
Areas naturally characterized by the presence of hilly relief often marked by the irregular occupation of slopes and their surroundings. This fact, which increases the risk associated to mass gravitational movements. This paper presents a risk analysis of mass movements in 16 slopes in the city of Aracaju, capital of the state of Sergipe, Brazil, using a qualitative method. Geotechnical characterization of soils from of slopes selected for analysis of stability was carried using the OptumG $2^{\circledR}$ software developed by Optum Computational Engineering using the Strength Reduction Method (SRM)
\end{abstract}

to obtain the safety factor. The aim of this study is to conduct a systematic analysis, associating subjective landslide risk studies with rational studies on slope stability analysis. It was found that $50 \%$ of the slopes analyzed exhibited a high or very high degree of risk, justifying the landslide risk management policies in the city. Moreover, stability analyses produced coherent results in terms of slope stability, whereby slopes with high and very high risk were classified as unstable, while the slope deemed to be stable presents medium risk of mass movements.

KEYWORDS: risk analysis, soil characterization, stability analysis.

\section{CARACTERIZAÇÃO GEOTÉCNICA E ANÁLISE DE RISCO DE INSTABILIDADE DE ENCOSTAS URBANAS DA CIDADE DE ARACAJU - BRASIL}

\begin{abstract}
RESUMO
Áreas naturalmente caracterizadas pela presença de relevo acidentado são muitas vezes marcadas pela ocupação irregular de encostas e do seu entorno. Fato esse, que eleva o risco associado a movimentos gravitacionais de massa. Este artigo apresenta uma análise de risco de movimentos gravitacionais de massa em 16 encostas existentes na cidade de Aracaju, capital do Estado de Sergipe - Brasil, empregando-se uma metodologia qualitativa. Também foi realizada a caracterização geotécnica dos solos dos taludes selecionados para a execução de análises de estabilidade utilizando-se o método de redução de resistência (MRR) para obtenção do fator de segurança. O objetivo desta
\end{abstract}

pesquisa é realizar uma análise mais sistêmica, associando os estudos de risco de deslizamentos, de caráter subjetivo, aos estudos racionais de análise de estabilidade de encostas. Foi possível constatar que $50 \%$ dos taludes analisados apresentaram grau de risco alto e muito alto, justificando-se a aplicação de políticas de gestão de risco de deslizamentos na cidade. Além disso, as análises de estabilidade forneceram resultados coerentes quanto à condição de estabilidade das encostas, em que as encostas com risco alto e muito alto foram classificadas como instáveis, enquanto a encosta julgada como estável apresenta risco médio a movimentos de massa.

KEYWORDS: análise de risco, caracterização dos solos, análise de estabilidade.

HOLOS, Ano 36, v.4, e10067, 2020 


\section{INTRODUCTION}

The illegal occupation of areas subject to mass movements in large urban centers accelerates these events, which often assume catastrophic proportions, given that cutting, backfills, the irregular reject of waste, deforestation, drainage conditions, and other aggressions strengthen the conditioning factors associated with the geomorphology of slopes (Benedet, 2015) . As such, it is important to conduct more systematic diagnoses and analyses, associating landslide risk studies with analyses of slope stability. These actions related to mass movement risk management in urban areas provides both in interventions by departments responsible for risk monitoring and to prevent the occupation of unstable urban areas, resulting in mapping to quantify and hierarchize geotechnical risk.

The first step in risk mapping is to select an analysis methodology to determine the nature and extent of risk, using analysis of potential risk and assessment of existing vulnerable conditions that might threaten life and damage property (UNI/ISDR, 2004). Risk analysis can be qualitative or quantitative. Qualitative analysis uses the degree of risk (low, medium, high, etc) or numerical scales $(1,2,3,4$, etc) to quantify risk. Quantitative analysis includes the numerical variables of vulnerability, probability and consequences. As such, risk is expressed in numerical values (Corteletti, 2014). Qualitative analysis can also function as a preliminary assessment, indicating the areas most prone to natural events and would therefore justify the use of quantitative analysis.

To complement risk analysis, slope risk is quantified based on stability analysis. The Finite Elements Method has been employed in analysis methods of this nature, characterized by determining simplified hypotheses considered in Limit Equilibrium Methods, primarily with respect to the stress-strain relation. Furthermore, the use of this method makes it possible not only to determine the safety factor but also to obtain the characteristics of the rupture mechanism.

The city of Aracaju, represented in Figure 1, is located in Northeastern Brazil. Despite being predominantly flat, displays different areas of rough terrain characterized by disorderly occupation and unsafe dwellings, in which clear cutting, landfills, deforestation and the absence of basic sanitation are some of the factors that contribute to the occurrence of landslides in these areas. This was, therefore, the main reason for conducting this research.

Accordingly, the aim of this study was to assess the landslide risk on 16 slopes of Aracaju, as well as conduct geotechnical characterization and slope stability analyses in order to relate the degree of risk with slope stability. As such, it is possible to assist the public entities responsible for risk management identify areas susceptible to events involving mass movements by studying the physical and environmental characteristics of the city.

Risk analyses were conducted based on qualitative methodology (Gusmão Filho et al., 1992). The method is completely subjective and effective in terms of the need to conduct 
preliminary hierarchization of risk of slopes, without requiring significant precision when determining the extent of risk. The geotechnical characterization of soils that make up the slopes selected for stability assessments involved grain size analysis tests, as well as Atterberg limits and direct shear tests. Slope stability was evaluated using the SRM (Strength Reduction Method), applying the Finite Element Method (FEM). The SRM is based on the principle that the safety factor is calculated from the relation between the shear strength of soil and shear stress that acts on the surface of the rupture. Therefore, it consists of the gradual decline in the shear strength of the soil, using FEM, until the first indications of rupture emerge (Krabbenhoft et al., 2015).

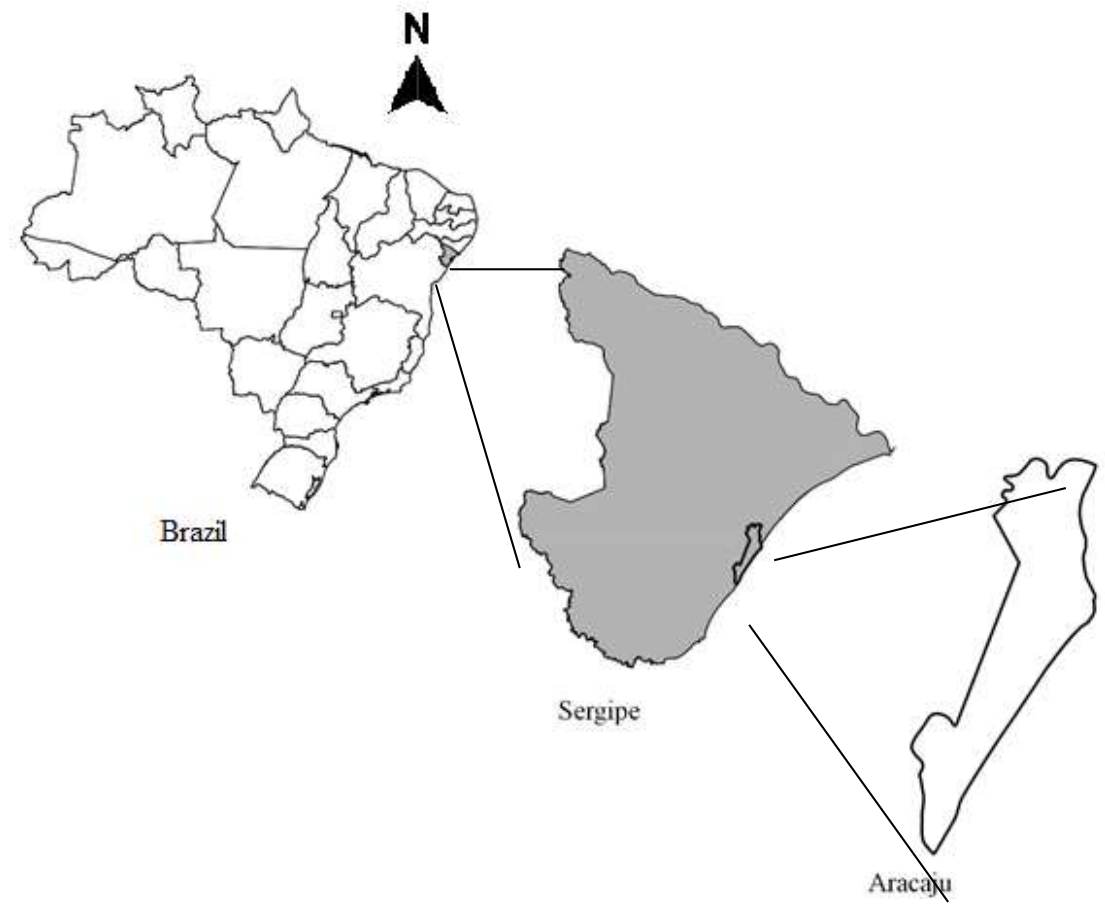

Figure 1: Geographic location of Aracaju city.

\subsection{Main aspects of Aracaju city}

Aracaju encompasses an area of $182.163 \mathrm{~km}^{2}$. In the 2019 census conducted by IBGE (Brazilian Institute of Geography and Statistics), the population of the city was 657,013 inhabitants.

Sergipe has three main climate zones: semiarid, arid and wet weather. Aracaju, located on the coast, is a tropical region, with high temperatures and humidity along the eastern coast. The state of Sergipe has irregular rainfall, which declines from the coast to the semiarid area. The highest annual rainfalls are recorded on the coastal strip of Aracaju, which exhibits three dry months, from December to February (Santos, 2012). Excessive rain is one of the primary causes of slope instability in the city, such as the $101.5 \mathrm{~mm}$ recorded in May 24, 2015, which caused serious problems for the population that inhabits areas susceptible to flooding and landslides in the city. In fact, May had the highest rainfall in 2015, 3-fold higher than the total recorded for the 3 dry months (BDMEP/INMET, 2015). 
The profiles of slopes in Aracaju are classified as concave, convex or both for natural slopes, and rectilinear in the case of artificial slopes. The geometric features of slopes are influenced by lithology and climate. In Aracaju, they are sculpted on the lithologies of the Barreiras Group, which consists mainly of clay (Araújo, 2006a). The city of Aracaju is located in a region covered by surface formations, represented by two relief units, namely, the Coastal Plain and Coastal Tablelands, characterized by the development of hills on the lithologies of the Barreiras Group (Araújo, 2006b). The Coastal Plain of Aracaju is composed of Quaternary marine (marsh and mangrove deposits) and Quaternary continental deposits (Fluvial-lagoon and coastal deposits). This unit is limited to the continental portion of the Barreiras Group. Hills were formed on the Coastal Tablelands, with predominance in the northern part of Aracaju, resulting in the highest rounded formations in the city, up to $100 \mathrm{~m}$ high. Coastal tablelands also extend into the western and southern parts of the city, where Barreiras Group outcrops occur. In other parts of the city, altimetric values are as low as $2 \mathrm{~m}$ (Araújo, 2006b).

\section{METHODOLOGY}

Figure 2 shows the location of the 16 slopes selected with the most representative characteristics for risk analyses, based on the survey of risk areas in terms of flooding and mass movements in Aracaju (CPRM, 2013). Stability analyses were conducted in slopes with the highest degree of risk in the four districts of the city. 


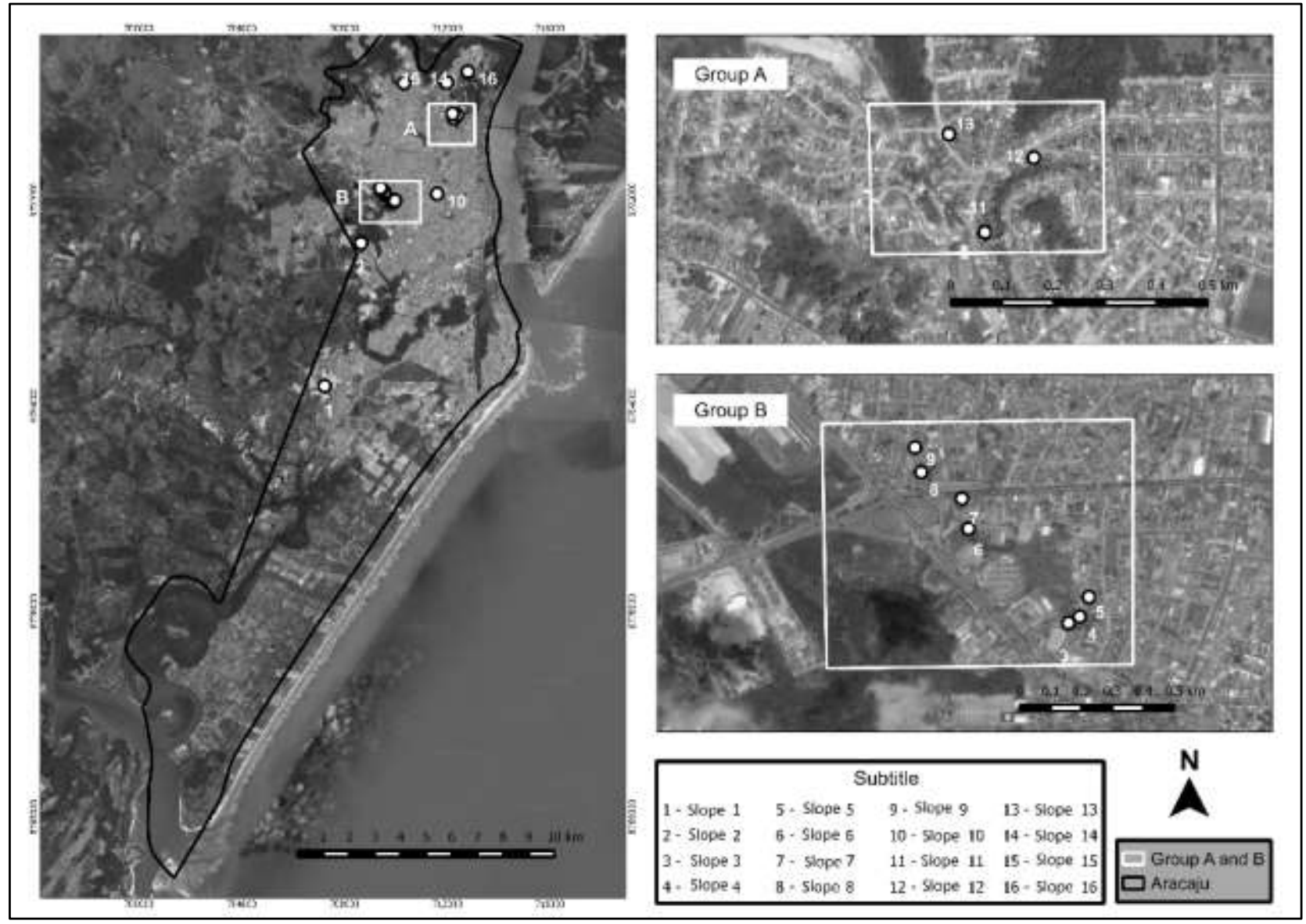

Figure 2: Representation of slope areas of Aracaju.

\subsection{Landslide risk analysis in Aracaju}

Degrees of risk were attributed by applying the qualitative methodology developed by Gusmão Filho et al. (1992), which considers the factors that influence the stability of the slopes. These factors are subdivided into groups of attributes. Calculating the degree of final risk for each slope followed the method proposed by Alheiros (1998).

The methodology involves compiling a risk assessment chart where the following factors are considered: topographic, geological and environmental, each with its respective attributes. Sanitation was added to the environmental factor, which corresponds to the existence or not of sewage treatment, according to Moura et al. (Moura et al., 2006). Four degrees of final risk were considered for the city of Aracaju: R1 (Low Risk), R2 (Medium Risk), R3 (High Risk) and R4 (Very High Risk).

Thus, it was possible to define the ranges corresponding to each risk level, as well as the linguistic terms for Aracaju, in Table 1.

Table 1: Range of Degrees of Risk of Attributes Corresponding to the Risk Factors.

\begin{tabular}{c|c|c|c|c}
\hline Factors & \multicolumn{4}{|c}{ Degree of risk } \\
\hline Topographic & Low - 1 & Medium - 2 & High - 3 & Very High - 4 \\
\hline Height (m) & $<10$ & $10-14$ & $14-18$ & $>18$ \\
\hline \hline HOLOS, Ano 36, v.4, e10067, 2020
\end{tabular}




\begin{tabular}{|c|c|c|c|c|}
\hline Extent $(\mathrm{m})$ & $<159$ & $159-302$ & $303-445$ & $>445$ \\
\hline Declivity (\%) & $<91$ & $91-135$ & $136-180$ & $>180$ \\
\hline Morphology (profile) & Concave & Rectilinear & Concave-convex & Convex \\
\hline Morphology (plant) & Convex & Rectilinear & Meandering & Concave \\
\hline Geological & Low - 1 & Medium - 2 & High - 3 & Very High - 4 \\
\hline Lithology & $\begin{array}{l}\text { Mature residual } \\
\text { soil }\end{array}$ & $\begin{array}{l}\text { Barreiras } \\
\text { Group }\end{array}$ & $\begin{array}{l}\text { Quaternary Unit } \\
\text { (Continental) }\end{array}$ & $\begin{array}{l}\text { Quaternary Unit } \\
\text { (Marine) }\end{array}$ \\
\hline Texture & Clayey-sand & Silty-sand & Sandy-clay & Sandy/Clayey \\
\hline Structure & Homogeneous & Opposite dip & Sub-horizontal & Sub-vertical \\
\hline $\begin{array}{c}\text { Mass movement and } \\
\text { transport }\end{array}$ & $\begin{array}{c}\text { Absent } \\
\text { Surface gullying }\end{array}$ & Scars & $\begin{array}{c}\text { Erosion at the foot of } \\
\text { the slope }\end{array}$ & $\begin{array}{l}\text { Deep gullying } \\
\text { Fissures }\end{array}$ \\
\hline Environmental & Low - 1 & Medium- 2 & High - 3 & Very high - 4 \\
\hline Vegetation (\%) & $>70$ & $70-30$ & $<30$ & Absent \\
\hline Drainage & $\begin{array}{c}\text { Extensive } \\
\text { Partial }\end{array}$ & Insufficient & Topical & Nonexistent \\
\hline Clear Cutting & Isolated & In plateaus & Disordered (-) & Disordered (+) \\
\hline $\begin{array}{c}\text { Population density } \\
\text { (inh/ha) }\end{array}$ & $<44$ & $44-70$ & $71-98$ & $>98$ \\
\hline Sanitation & $\begin{array}{c}\text { Sewage totally } \\
\text { treated }\end{array}$ & $\begin{array}{c}\text { Treatment } \\
\text { plant }\end{array}$ & Septic tank & $\begin{array}{c}\text { Improper wastewater } \\
\text { disposal }\end{array}$ \\
\hline Treatment & $\begin{array}{c}\text { Extensive } \\
\text { Partial }\end{array}$ & Insufficient & Topical & Nonexistent \\
\hline
\end{tabular}

Topographic, geological and environmental risks were calculated using the arithmetic mean of risk values assigned to their respective attributes. Equations (1) to (3) present the calculations topographic, geological and environmental risks.

$$
\begin{aligned}
& T R=\frac{\sum \text { Attributes }}{5} \\
& G R=\frac{\sum \text { Attributes }}{4} \\
& E R=\frac{\sum \text { Attributes }}{5}
\end{aligned}
$$

Where $T R, G R$ and $E R$ correspond to topographic, geological and environmental risks, respectively.

This study considered the reducing factor of environmental risk due to treatment (Alheiros, 1998), considering the four degree of risk ranges, expressed in Equation (4).

$$
R A_{t}=R A_{i}-\left[\left(\frac{R A_{i}-1}{3}\right) \cdot(4-T)\right]
$$


Where $R A_{t}$ is the risk of an environmental attribute including treatment, $R A_{i}$ corresponds to the risk of an environmental attribute without treatment and $T$ is the treat-ment score (between 1 and 4).

The final risk was calculated based on the proposal of Alheiros (Alheiros, 1998), attributing a weight of 2 for the topographic factor, 1 for the geological factor and 3 for the environmental factor, in Equation (5).

$$
F R=\left[\frac{(2 T R)+(1 G R)+\left(3 E R_{t}\right)}{6}\right]
$$

In Equation (5), $F R$ is the final risk of the slope, $T R$ the topographic risk, $G R$ the geological risk and $E R_{t}$ the environmental risk including the treatment score.

\subsection{Geotechnical Characterization}

The slopes 1, 3, 11 and 14 were selected for stability analysis using strength reduction methodology. These slopes represent the greatest risk to the areas in which they are located, according to qualitative risk analysis.

The remaining tests were carried out with chips of undisturbed blocks separated during the molding of test specimens used in direct shear testing, except characterization of slope 14 soil, conducted on a disturbed sample. The samples used in soil characterization tests were prepared according to ME standard 041 (DNER, 1994a). Grain size analysis tests and Atterberg limits were in accordance with NBR standards 6459, 7180 and 7181 (ABNT, 1984a, 1984b, 1984c), respectively. Grain density tests were based on ME standard 093 (DNER, 1994b).

Direct shear tests were conducted with test specimens of undisturbed samples collected on the slopes selected for stability analyses according to standard D3080 (ASTM, 2011), under consolidated and drained conditions. Three test specimens were analyzed in the flooded conditions for each soil. The test specimens from slopes 3, 11 and 14 were analyzed under normal stresses of 50, 150 and $300 \mathrm{kPa}$. Those from slope 1 were tested under normal stresses of 100, 200 and $300 \mathrm{kPa}$. The shear speed of the samples from slopes 1,11 and 14 was $0.1 \mathrm{~mm} / \mathrm{min}$, while those from slope 3 were sheared at $0.08 \mathrm{~mm} / \mathrm{min}$.

\subsection{Slope stability analyses}

Stability analysis of the slopes was conducted using the OptumG $2^{\circledR}$ program developed by Optum Computational Engineering, which uses the direct finite elements method to define the safety factor of the slopes.

The program provides the safety factor in the stability analysis of slopes using Gravity Increase Method (GIM) and Strength Reduction Method (SRM). In this study SRM was selected to obtain the safety factors of the slopes under study. Strength reduction analysis is based on the calculation of the factor by which the strength parameters of the material needs to be reduced to reach the initial state 
of collapse. The same factor must be used to reduce cohesion and the friction angle (c, $\tan \phi)$ of the material that makes up the slope. Thus, it is possible to determine the strength reduction factor that is equivalent to the safety factor calculated using the Strength Reduction Method, applying Equation (6).

$$
F S_{s}=\frac{c}{c_{c r}}=\frac{\tan \phi}{\tan \phi_{r e d}}
$$

In Equation (6), $F S_{S}$ is the safety factor of the slope, $c$ and $\tan \phi$ are cohesion and the friction angle, respectively and $c_{c r}$ and $\tan \phi_{\text {red }}$ are their values critics.

The analyses developed by the program enable the use of an adaptive finite elements grid and select a certain number of adaptability interactions to refine the grid, as well as define the number of elements in the initial grid and the control variable to which the grid must be adapted (Krabbenhoft et al., 2015). OptumG2 ${ }^{\circledR} 2016.08 .19$ provides safety factors in terms of lower and upper limits, whereby the value of the safety factor that defines the stability condition belongs to the range between the values of the two limits.

Analyses were conducted disregarding the generation of neutral pressures, that is, prolonged analyses, since effective strength parameters are involved. One thousand elements were used for the initial finite elements grid. An adaptive grid was used with 3 adaptations according to plastic shear strain. On slopes with any type of building at the foot or top of the slope, a value of $25 \mathrm{kPa}$ was used for the overload in all buildings, due to the lack of knowledge of the overload produced in each situation. This value was obtained from Menezes et al. (2016), who studied the size of low-income housing, which is the case of the dwellings found in the risk areas of Aracaju.

Based on a planialtimetric survey, it was possible to determine the most unfavorable profiles for stability analyses, that is, the profile with the steepest inclination of each slope. The profiles used in stability analyses of the slopes 1, 3, 11 and 14 are shown in Figures 3 to 6.

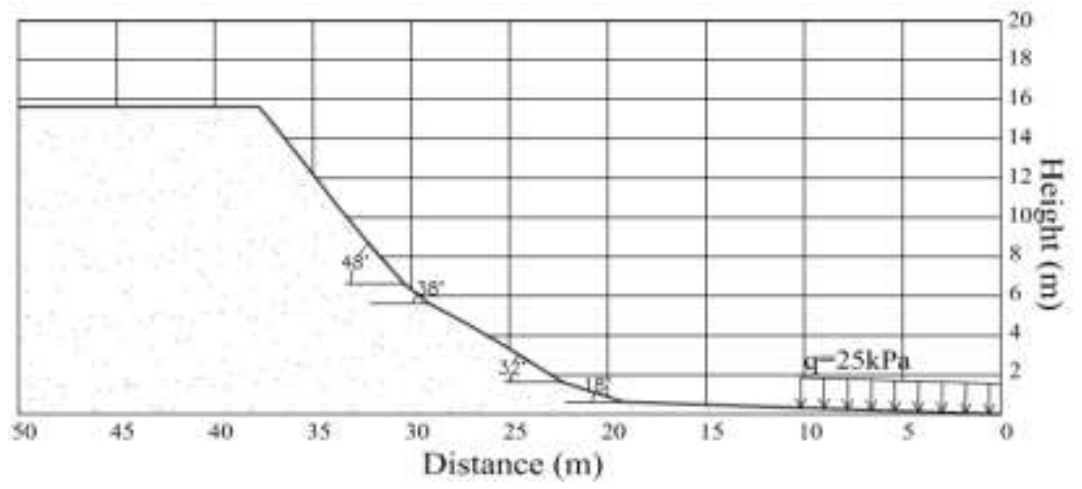

Figure 3: Profile of the slope 1. 


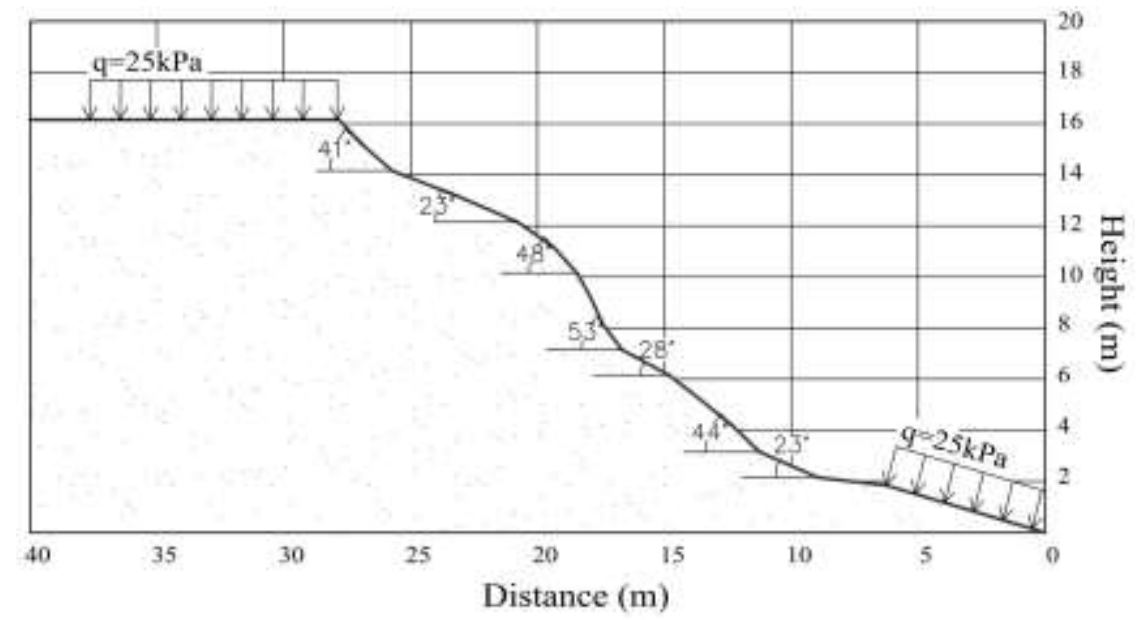

Figure 4: Profile of the slope 3.

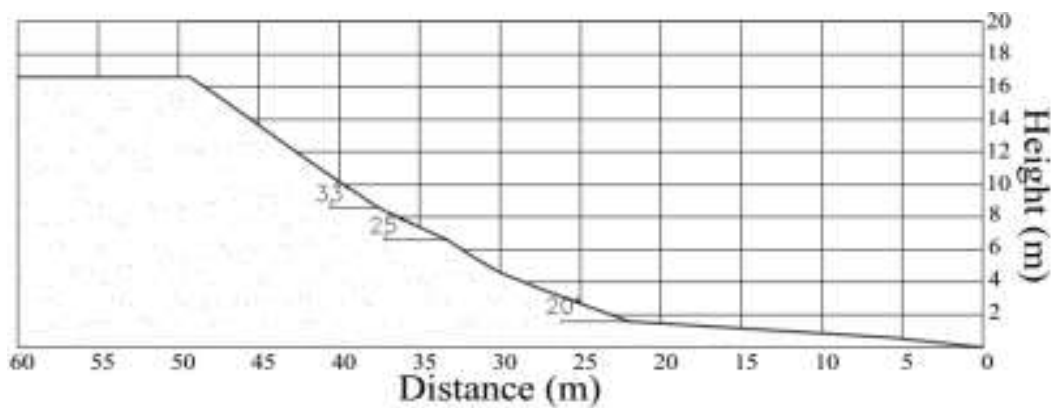

Figure 5: Profile of the slope 11.

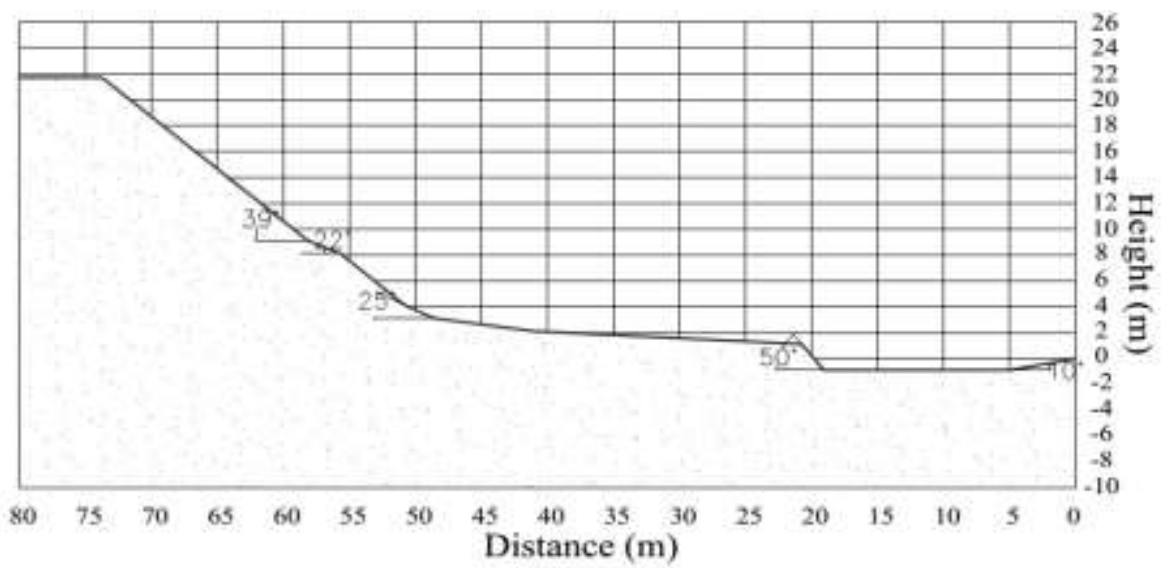

Figure 6: Profile of the slope 14.

\section{RESULTS AND DISCUSSIONS}

Risk analysis determined the ranges corresponding to each degree of risk, as shown in Table 2.

Table 2: Degree of risk ranges of Aracaju.

\begin{tabular}{c|c}
\hline Degree of risk & Final risk \\
\hline Low Risk & $<2.14$ \\
\hline Medium Risk & $2.14-2.40$ \\
\hline High Risk & $2.41-2.67$ \\
\hline
\end{tabular}




\begin{tabular}{c|c}
\hline Very High Risk & $>2.67$ \\
\hline
\end{tabular}

The values of final risk, degree of risk attributed to the slopes and the region to which they belong are illustrated in Table 3. These data show that the results obtained were compatible with the risk characteristics exhibited in the field.

Table 3: Degrees of risk per slopes in Aracaju.

\begin{tabular}{|c|c|c|c|}
\hline Slopes & Regions & Final Risk & Degree of Risk \\
\hline 01 & South & 2.23 & Medium Risk \\
\hline 02 & \multirow{9}{*}{ West } & 2.72 & Very High Risk \\
\hline 03 & & 2.93 & Very High Risk \\
\hline 04 & & 2.33 & Medium Risk \\
\hline 05 & & 2.52 & High Risk \\
\hline 06 & & 2.27 & Medium Risk \\
\hline 07 & & 2.37 & Medium Risk \\
\hline 08 & & 2.40 & Medium Risk \\
\hline 09 & & 2.80 & Very High Risk \\
\hline 10 & & 2.36 & Medium Risk \\
\hline 11 & \multirow{6}{*}{ North } & 2.54 & High Risk \\
\hline 12 & & 1.88 & Low Risk \\
\hline 13 & & 2.37 & Medium Risk \\
\hline 14 & & 2.63 & High Risk \\
\hline 15 & & 2.55 & High Risk \\
\hline 16 & & 2.41 & High Risk \\
\hline
\end{tabular}

The Unified Soil Classification System (USCS) was adopted to classify hillside soils. The characteristics of the soils analyzed are depicted in Table 4. The soils selected for stability analyses exhibit coarse grain size, that is, composed of more than $50 \%$ gravel and sand. According Jenkins (Caputo, 2011), the soils of slopes 1 and 14 are highly plastic, with plasticity indexes higher than $15 \%$, which corresponds to the highest clay percentages. The soil from slope 3 is non-plastic (NP), which may be attributed to the high percentage of silt, given that silts and coarse soils exhibit little or no plasticity. The soil from slope 11 was classified as slightly plastic, with $1 \%<\mathrm{PI}<7 \%$. The low plasticity index may be attributed to the fact that the soil displays a low percentage of fine grains in its composition and a low clay activity index (Skempton, 1953) of 0.32.

The parameters of strength, cohesion and friction angle $\left(c^{\prime}, \phi^{\prime}\right)$ were obtained from direct shear tests, and defined based on the peak strength envelope of the tests. The soil properties and strength parameters obtained in shear tests are shown in Table 5.

The soil from slope 1 showed the highest cohesion intercept value, when compared to the other soils $(20.5 \mathrm{kPa})$, which can be explained by the high percentage of clay in the soil and the high plasticity index (PI). In relation to the effective friction angle $\left(\phi^{\prime}\right)$, the value obtained was $32.6^{\circ}$. The cohesive intercept obtained in the slope 3 sample was null, possibly due to the collapsible behavior that the soil exhibited when flooded in the direct shear consolidation phase in the first stress stage. In this case, a decrease in test specimen height of around $16 \%$ was observed after 
only 15 minutes of first stage stress application $(50 \mathrm{kPa})$. The friction angle obtained was $31.5^{\circ}$. The slope 11 soil exhibited a high percentage of sand and, as expected, low PI value, which resulted in the very low cohesion value obtained $(1.4 \mathrm{kPa})$. The internal friction angle was $34.4^{\circ}$. The slope 14 sample also showed a low cohesion value of $7.9 \mathrm{kPa}$. As expected, due to the high sand percentage, despite the sand's highly plastic classification because of the presence of clay, the internal friction angle obtained was $32.9^{\circ}$.

Table 4: Characteristics of the soils analyzed.

\begin{tabular}{c|c|c|c|c}
\hline Characteristics & Slope 1 & Slope 3 & Slope 11 & Slope 14 \\
\hline$w(\%)$ & 4.00 & 1.85 & 2.47 & 2.10 \\
\hline Gravel (\%) & 4.02 & 4.34 & 4.25 & 0.10 \\
\hline Sand (\%) & 50.38 & 61.99 & 69.48 & 64.53 \\
\hline Silt (\%) & 9.99 & 15.75 & 6.54 & 11.33 \\
\hline Clay (\%) & 35.62 & 17.92 & 19.74 & 24.05 \\
\hline$w_{L}(\%)$ & 38 & & 20 & 32 \\
\hline$w_{P}(\%)$ & 21 & NP & 14 & 16 \\
\hline PI (\%) & 17 & & 6 & 16 \\
\hline$\gamma_{g}\left(g / c^{3}\right)$ & 2.68 & 2.66 & 2.65 & 2.65 \\
\hline Soil Classification (USCS) & SC & SM & SC-SM & SC \\
\hline
\end{tabular}

$w=$ hygroscopic moisture content; $w_{L}=$ liquid limit; $w_{P}=$ plastic limit; $\mathrm{NP}=$ non-plastic; $\mathrm{PI}=$ plasticity index; $\gamma_{g}=$ grain density; $S C=$ clayey sand; $S M=$ silty sand; $S C-S M=$ silty-clayey sand.

Table 5: Properties of the soils studied.

\begin{tabular}{c|c|c|c|c}
\hline Properties & Slope 1 & Slope 3 & Slope 11 & Slope 14 \\
\hline$w_{i}(\%)$ & 6.6 & 2.8 & 3.3 & 5.1 \\
\hline$w_{f}(\%)$ & 21.3 & 18.4 & 14.8 & 18.9 \\
\hline$\gamma\left(\mathrm{kN} / \mathrm{m}^{3}\right)$ & 17.0 & 15.8 & 17.5 & 17.3 \\
\hline$\gamma_{d}\left(\mathrm{kN} / \mathrm{m}^{3}\right)$ & 15.9 & 15.4 & 16.9 & 16.5 \\
\hline$\gamma_{s a t}\left(\mathrm{kN} / \mathrm{m}^{3}\right)$ & 20.0 & 19.6 & 20.6 & 20.3 \\
\hline$e_{i}$ & 0.68 & 0.73 & 0.56 & 0.61 \\
\hline$n(\%)$ & 40.4 & 42.1 & 36.1 & 37.8 \\
\hline$S_{r i}(\%)$ & 25.9 & 10.3 & 15.4 & 22.4 \\
\hline$c^{\prime}(\mathrm{kPa})$ & 20.5 & 0.0 & 1.4 & 7.9 \\
\hline$\phi^{\prime}\left({ }^{\circ}\right)$ & 32.6 & 31.5 & 34.4 & 32.9 \\
\hline
\end{tabular}

$w_{i}=$ initial moisture content; $w_{f}=$ final moisture content; $\gamma=$ weight density; $\gamma_{d}=$ dry density; $\gamma_{\text {sat }}=$ zero air voids density; $e_{i}=$ initial void ratio; $n=$ porosity; $S_{r i}=$ initial degree of saturation; $c^{\prime}=$ effective cohesion; $\phi^{\prime}=$ effective friction angle.

The geotechnical characterization of hillside soils in the selected slopes according to risk analysis, resulted in a sample of the soil properties from different regions of the city, where soils were obtained with varying classifications and strength. The properties and strength parameters were obtained from undisturbed samples to mold test specimens for testing under flood conditions. In addition to obtaining a sample of soils from different regions of the city, the aim of geotechnical characterization tests was also to conduct stability analyses of the slopes selected. 
Knowledge of the strength characteristics and parameters of soils made it possible to model the slopes using the OptumG $2{ }^{\circledR}$ software and submit them to stability analyses. The analyses developed from the strength parameters obtained under the flood condition enabled determining the scenarios triggered by saturation of slope materials caused by high rainfall, for example.

The stability condition of slopes, in terms of the safety factor, was defined according to NBR 11682 (ABNT, 2009). The minimum safety factor for the slope to be considered stable is 1.4. After stability analyses, it was possible to define the safety condition of the slopes under study. The safety factors obtained from stability analyses and slope stability according to NBR 11682 (ABNT, 2009) are summarized in Table 6, whereby only one of the 4 slopes analyzed is considered stable.

Table 6: Safety condition of the slopes under study.

\begin{tabular}{c|c|c}
\hline Slope & SF & Safety \\
\hline 1 & $1.76 \pm 0.01$ & Stable \\
\hline 3 & $0.37 \pm 0.05$ & Unstable \\
\hline 11 & $1.24 \pm 0.01$ & Unstable \\
\hline 14 & $1.23 \pm 0.01$ & Unstable \\
\hline
\end{tabular}

The finite elements grids indicating the potential for surface rupture of the slopes under study and distribution of strain $(x, y)$ are presented in Figures 7 to 10.

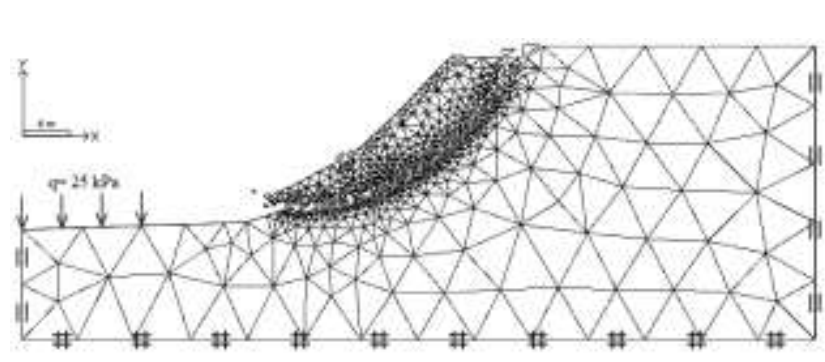

a)

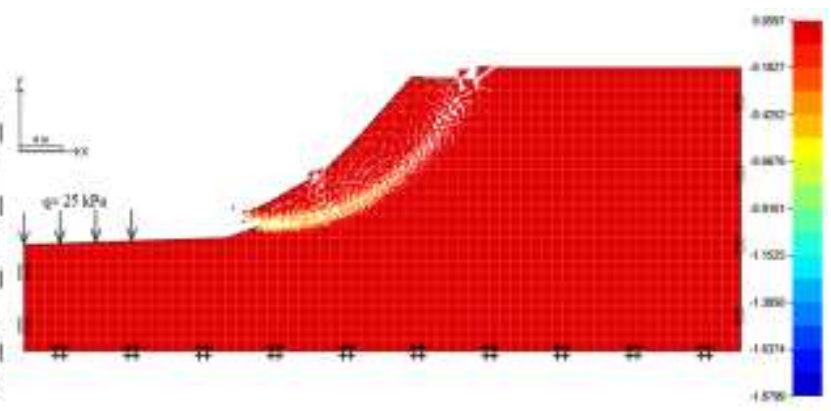

b)

Figure 7: Stability analysis in slope 1 - a) Finite elements grid; b) Strains.

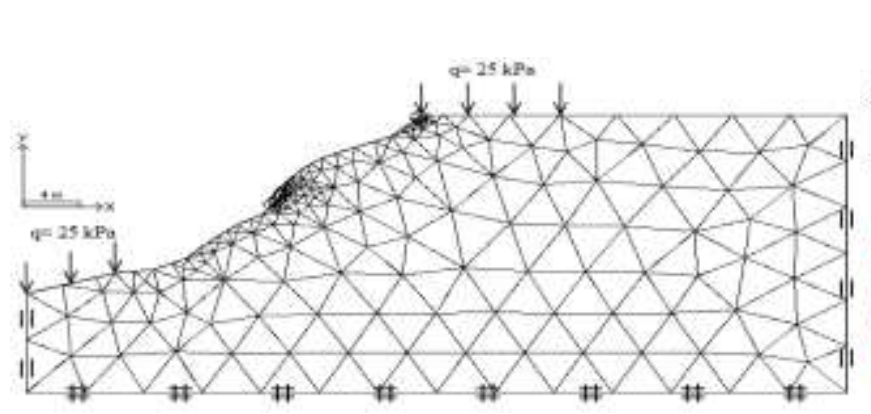

a)

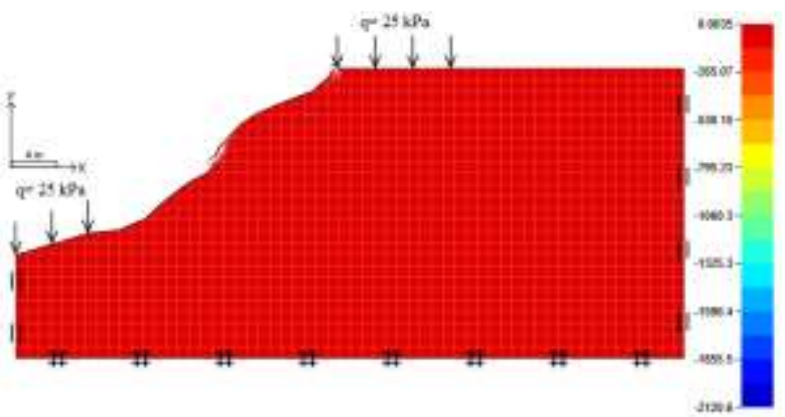

b)

Figure 8: Stability analysis in slope 3 - a) Finite elements grid; b) Strains. 


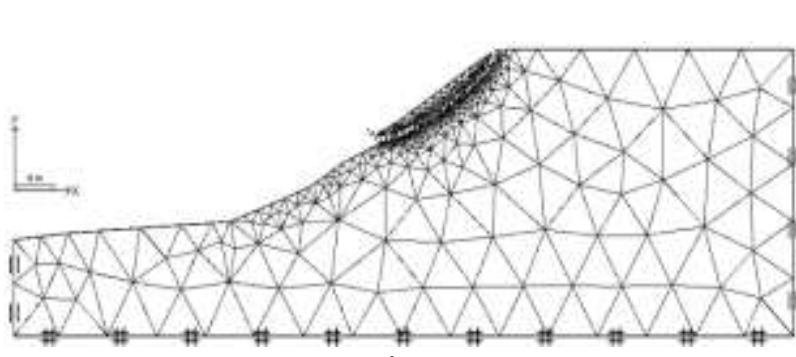

a)

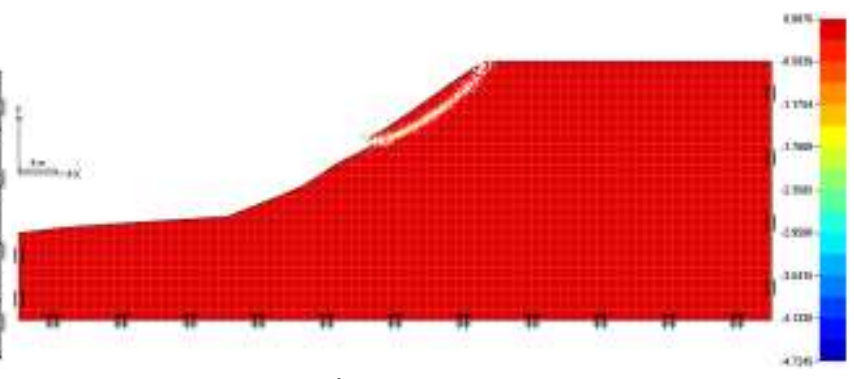

b)

Figure 9: Stability analysis in slope 11 - a) Finite elements grid; b) Strains.

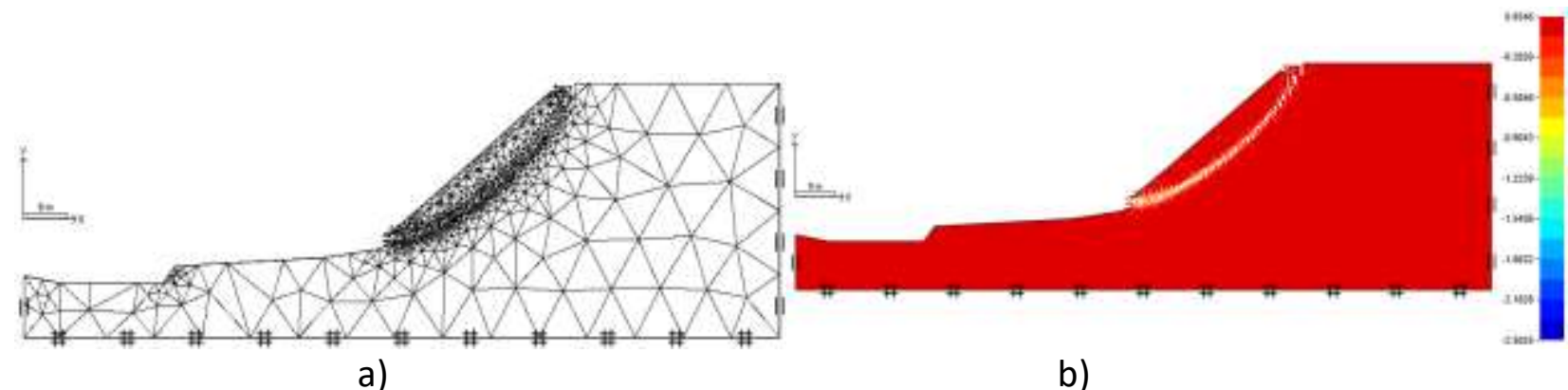

Figure 10: Stability analysis in slope 14 - a) Finite elements grid; b) Strains.

The finite elements grid is refined exactly where the rupture surface is placed, given that grid adaptability occurs according to plastic strains caused by shearing. The potential rupture surface assumes a circular shape, but wedge failure is not very deep. The slope 1 showed a safety factor of more than 1.4, the highest among the slopes analyzed, in line with the highest cohesive intercept value obtained.

The cohesive intercept of slope 3 soil was null, which is reflected in the low safety factor. The soil does not need to be totally saturated for the slope to collapse, since the safety factor of the flooded soil was less than 1 (one), the general condition for slope instability. This condition is compatible with the physical indicators of instability observed on the hillside.

Stability analysis with a null cohesion value resulted in a non-circular and superficial rupture surface. The results show the need to monitor this area, given the considerable number of dwellings in precarious positions.

Stability analysis of the slope 11 produced a safety factor of less than 1.4. As such, when high rainfall occurs, resulting in significant soil saturation, the slope may rupture. Due to the significant urbanization of slope 11 , the damage caused by a possible slope rupture could be disastrous. The surface of the collapsed slope is circular with a low volume of mobilized material.

With respect to analysis conducted on the slope 14 , the safety factor calculated was less than 1.4. Thus, the slope shows great potential of becoming unstable. This condition is compatible with the occurrences of mass movements in this area. The rupture surface was circular and superficial, with a low volume of mobilized material. 
Another finding is that all rupture surfaces of the unstable slopes were shallow, that is, the slope does not need to be totally saturated for rupture to occur, rather, it is sufficient for the soil to be saturated beyond the potentially sliding surface.

Finally, it is important to underscore that slope stability is in line with the degree of risk attributed to the slopes, since the only slope 1 was considering stable, where a medium degree of risk was attributed. With respect to the remaining slopes, which exhibited safety factors below the minimum needed to be considered stable, slopes 11 and 14 were classified as high risk, whereas slope 3 showed a very high degree of risk.

\section{CONCLUSIONS}

In the present study, risk analysis was conducted in 16 slope in the city of Aracaju, $6 \%$ of which displayed a low degree of risk, $44 \%$ medium, $31 \%$ high and $19 \%$ very high.

The geotechnical characterization of soils from slopes selected according to risk analysis, resulted in a representative sampling of soil properties from different regions of the city. As such, soils were obtained with varying classifications and strength parameters.

The geotechnical characterization provided the properties and parameters of soil strength, necessary for conducting stability analyses. Soil from the Santa Maria district (slope 1) was classified as highly plastic clayey sand (SC). The material obtained a cohesive intercept value of $20.5 \mathrm{kPa}$ and friction angle of $32.6^{\circ}$. These values coincide with the safety factor of the slope, considered the only stable.

The material collected in the America district was characterized as silty sand (SM) with no plasticity, a null cohesion intercept and friction angle of $31.5^{\circ}$. Material collected in the Industrial district displayed silty-clay sand (SC-SM) characteristics and weak plasticity, with a cohesive intercept value of $1.4 \mathrm{kPa}$ and friction angle of $34.4^{\circ}$. Finally, in the Japãozinho district, the soil collected was strongly plastic clayey sand (SC), the cohesive intercept was $7.9 \mathrm{kPa}$ and friction angle $32.9^{\circ}$. The low values of the strength parameters justify the instability of the slopes.

In addition to safety factors, stability analysis showed the location of rupture surfaces and the collapse mechanism of slopes. The results of stability analyses were in line with the risk classification of the slopes. The only slope that remained stable presented a medium degree of risk. The remaining slopeswith high and very high degrees of risk, were unstable. The wedge failures obtained from the analyses were superficial, involving a low volume of mobilized material. This explains why the mass movements that have occurred in these areas have yet to cause a major disaster.

It is important to underscore the need to foresee the damage that could be caused by heavy rainfall that saturates the soils of these slopes. Although intense rainfall is not frequent in Aracaju, there are exceptional cases that have disrupted the communities located in these areas. 
The results obtained in the study of risk areas in Aracaju were considered satisfactory and promising for the desired purpose, since it contemplated different analytical methods in order to assist the entities responsible for risk management in the city and encourage more studies in the area.

\section{REFERENCES}

Alheiros, M.M. (1998). Riscos de Escorregamentos na Região Metropolitana do Recife. Tese de Doutorado, Universidade Federal da Bahia, Salvador, Bahia, Brasil.

Araújo, H.M. (2006a). Encostas no Ambiente Urbano de Aracaju. In Araújo, H.M.; Vilar, J.W.C.; Wanderley, L.L.; \& Souza, R.M. (Org.). O Ambiente Urbano: visões geográficas de Aracaju (pp. 247-265). São Cristóvão: Universidade Federal de Sergipe.

Araújo, H.M. (2006b). In Araújo, H.M.; Vilar, J.W.C.; Wanderley, L.L.; \& Souza, R.M. (Org.). O Ambiente Urbano: visões geográficas de Aracaju (pp. 15-42). São Cristóvão: Universidade Federal de Sergipe.

ASTM D3080 (2011). Direct Shear Test of Soils under Consolidated Drained Conditions. West Conshohocken: ASTM.

Benedet, C. (2015). Análise dos Processos de Movimentos Gravitacionais de Massa nas Encostas dos Bairros Prado e Saudade e Área Adjacente a BR - 101 no Município de Biguaçu (SC) Integrando as Características dos Sítios aos Fatores de Uso e Ocupação Urbana. Tese de Doutorado, Universidade Federal de Santa Catarina, Florianópolis, Santa Catarina, Brasil.

Caputo, H.P. (2011). Mecânica dos solos e suas aplicações. Rio de Janeiro: LTC.

Corteletti, R.C. (2014). Proposta de Metodologia para Análise de Riscos Geológico-Geotécnicos em Ferroviais. Tese de Doutorado, Universidade Federal de Ouro Preto, Ouro Preto, Minas Gerais, Brasil.

DNER ME 041 (1994a). Solos - Preparação de Amostras para Ensaios de Caracterização. Brasília: DNER.

DNER ME 093 (1994b). Solos - Determinação da Densidade Real. Brasília: DNER.

Gusmão Filho, J.A., Melo, L.V., \& Alheiros, M.M. (1992). Plano Diretor de Jaboatão dos Guararapes: Relatório Temático sobre Encostas, Brasil, $50 \mathrm{p}$.

Instituto Nacional de Meteorologia (2015). Banco de Dados Meteorológicos para Ensino e Pesquisa [Online].

Krabbenhoft, K., Lymain, A.V., \& Krabbenhoft, J. (Ed.) (2015). OptumG2. Optum Computational Engineering [Online]. 
Menezes, L.M.R., Santos, D. S., Melo, F. G. S., Santos, E. W. F., \& Conceição, R. S. (2016). Estudo para Dimensionamento de Estrutura em Concreto Armado para Edificações Populares. Congresso Brasileiro do Concreto, Belo Horizonte, MG, 16.

Moura, D.S.S., Severo, R.N.F, Júnor, O. F. S, Neto, O. F., \& Pereira, A. C. (2006). Mapeamento de risco simplificado de deslizamento de encostas no município de Tibau do Sul - $R N$. Procedimentos do I Congresso de Pesquisa e Inovação da Rede Norte Nordeste de Educação Tecnológica, Natal, RN, Brasil, 10.

NBR 11682 (2009). Estabilidade de Encostas. Rio de Janeiro: ABNT.

NBR 6459 (1984a). Solo - Determinação do Limite de Liquidez. Rio de Janeiro: ABNT.

NBR 7180 (1984b). Solo - Determinação do Limite de Plasticidade. Rio de Janeiro: ABNT.

NBR 7181 (1984c). Solo - Análise Granulométrica. Rio de Janeiro: ABNT.

Santos, A. (2012). Riscos Geológicos e Hidrológicos em Aracaju. Dissertação de Mestrado, Universidade Federal de Sergipe, São Cristóvão, Sergipe, Brasil.

Serviço Geológico do Brasil (2013). Ação Emergencial para Delimitação de Áreas em Alto e Muito Alto Risco a Enchentes e Movimentos de Massa. Sergipe: Authors.

Skempton, A. W. (1953). The colloidal activity of clays (pp. 57-61). 3 International Conference of Soil Mechanics and Foundation Engineering.

United Nations Inter Agency Secretariat of the International Strategy for Disaster Reduction (UNI/ISDR). (2004). Living with Risk: A Global Review of Disaster Reduction Initiatives. United Nations Organization (UNO). Genebra: Authors.

\section{COMO CITAR ESTE ARTIGO:}

Santos Neta, B.G., Freitas Neto, O., Cavalcante, E.H. (2020). Geotechnical characterization and risk analysis of urban slope instability in the city of Aracaju-Brazil. Holos, 36(4), 1-17.

\section{SOBRE OS AUTORES}

\section{BELANIZA GASPAR SANTOS NETA}

Doutoranda em Geotecnia pela Universidade de Brasília - UnB, Mestre em Engenharia Civil pela Universidade Federal de Sergipe - UFS (2016), Engenheira Civil formada pela Faculdade Pio Décimo (2013), Técnica em Edificações pelo Instituto Federal de Sergipe - IFS (2008). Atuou como professora substituta nos cursos de Engenharia Civil e Técnico de Edificações no Instituto Federal de Sergipe, atuou como professora assistente em instituições privadas. Os principais interesses em pesquisa são: estabilidade de encostas, fundações, ensaios de laboratório e de campo em solos, modelagem e simulação numérica de problemas de Engenharia Geotécnica. Com trabalhos publicados e apresentados em congressos de nível nacional e internacional, além de publicação de capítulo de livro sobre Engenharia Geotécnica. E-mail: belanizagsn@gmail.com.

ORCID ID: https://orcid.org/0000-0002-1877-9353 


\section{OSVALDO DE FREITAS NETO}

Engenheiro Civil formado pela Universidade Federal do Rio Grande do Norte - UFRN (2006), Mestre em Geotecnia pela Universidade de São Paulo - EESC (2008) e Doutor em Engenharia Civil pela Universidade de Brasília - UnB (2013). Atualmente é Professor Efetivo do Departamento de Engenharia Civil da Universidade Federal Rio Grande do Norte, onde atua nos cursos de Graduação e Pós-Graduação e em Engenharia Civil (PEC-UFRN). Tem como principais interesses em pesquisa: Fundações, Estabilidade de Encostas, Ensaios de Laboratório e de Campo em Solos Saturados e Não Saturados, Estruturas de Contenção, Melhoramento de Solos e Simulações Numéricas de Problemas de Engenharia Geotécnica. Tem diversos trabalhos publicados em revistas, congressos e simpósios de nível nacional e internacional e experiência na elaboração de Projetos e prestação de Consultoria e Assessoria Técnica em Geotecnia. E-mail: osvaldocivil@ufrn.edu.br. ORCID ID: https://orcid.org/0000-0001-9488-4123

\section{ERINALDO HILARIO CAVALCANTE}

Professor Titular do Departamento de Engenharia Civil da Universidade Federal de Sergipe. Engenheiro Civil, em 1994, e mestrado em 1997, em Geotecnia na Universidade Federal da Paraíba (Campus II - Campina Grande). Doutor em Engenharia Civil (Geotecnia), pela COPPE/Universidade Federal do Rio de Janeiro, em 2002. É professor da UFS, campus-sede, em Aracaju, desde abril/2003, onde implantou e coordena o Laboratório de Geotecnia e Pavimentação. Foi o primeiro coordenador do Programa de Pós-Graduação em Engenharia Civil da UFS, o primeiro mestrado acadêmico em Engenharia Civil de Sergipe, o qual coordenou nos seus primeiros 4 anos, onde atua como docente permanente. Acumula mais de 50 orientações e coorientações de mestrado, doutorado, Iniciação científica, Estágio e TCC, e contabiliza mais de 60 artigos científicos publicados em periódicos e eventos científicos nacionais e internacionais. É membro titular do Conselho do Ensino, da Pesquisa e Extensão da UFS. Há vários anos atua como avaliador de Instituições de Educação Superior e de cursos superiores da área de Engenharia, a serviço do INEP/MEC. É membro de comitês científicos de vários periódicos, entre eles a revista Matéria, da UFRJ, a Revista Transportes, a Revista Eletrônica de Engenharia Civil da UFG e a revista Soils \& Rocks. É consultor Ad hoc CAPES. Há mais de 20 anos é sócio representativo da ABMS - Associação Brasileira de Mecânica dos Solos e Engenharia Geotécnica, atuando na área de Investigações do Subsolo, Fundações e Obras de Terra. E-mail: erinaldohc@gmail.com.

ORCID ID: https://orcid.org/0000-0001-5859-1956

Editor(a) Responsável: Fábio Augusto Procópio Paiva

Pareceristas Ad Hoc: Jaquelígia Silva e Paulo Filipe Lopes

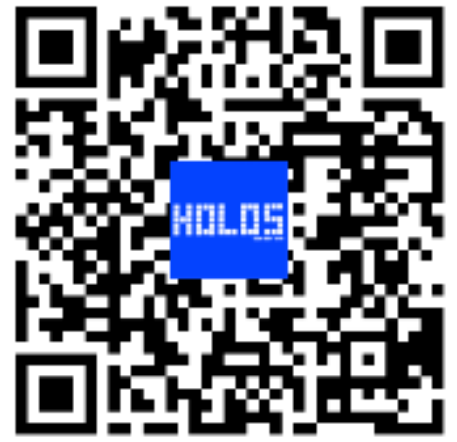

Recebido: 07 de maio de 2020

Aceito: $\mathbf{2 8}$ de maio de $\mathbf{2 0 2 0}$

Publicado: 01 de julho de 2020 